\title{
The moose, purine degradation, and environmental adaptation
}

\author{
Weiqi Zhang $\cdot$ Philip Stott $\cdot$ Minghai Zhang
}

Received: 14 October 2013 / Accepted: 24 September 2014 /Published online: 1 October 2014

(C) The Author(s) 2014. This article is published with open access at Springerlink.com

\begin{abstract}
It is accepted that allantoin is the end-product of purine degradation in mammals, except that uricase activity has been lost during the evolution of humans in which uric acid protects the brain from oxidative damage. However, we have found that the moose Alces americanus excretes extremely low urinary concentrations of allantoin and high concentrations of uric acid very similar to those of humans. Exposure to extreme cold is known to cause oxidative damage, and we suggest that the retention of uric acid by the moose represents an adaptation enabling the species to survive at high latitudes.
\end{abstract}

Keywords Alces americanus $\cdot$ China $\cdot$ Purine degradation . Uric acid

\section{Introduction}

It is generally accepted that low concentrations of plasma uric acid occur in non-primate mammalian species (Cutler 1984). However, in 1959 it was pointed out that the conclusion that all mammals other than primates have uricase capability is based on studies of a limited number of species (Keilin 1959). The seminal data for concentrations of purine derivatives in ungulate urine

Communicated by C. Gortázar

W. Zhang $\cdot$ M. Zhang $(\bowtie)$

College of Wildlife Resources, Northeast Forestry University, 26

Hexing Road, Harbin, Heilongjiang 150040, People's Republic of

China

e-mail: zhangminghai2004@126.com

P. Stott

School of Animal and Veterinary Sciences, The University of

Adelaide, Roseworthy, SA 5371, Australia was provided by Hunter and Givens (1914), who examined the major domestic ungulates, and found that purine derivatives were mostly to almost always excreted as allantoin. Since then, all published studies of mammals other than primates have confirmed the primacy of allantoin as the end-product of purine degradation, including additional studies in ruminants such as sheep (Bristow et al. 1992; Surra et al. 1997), goats (Belenguer et al. 2002; Bristow et al. 1992), cattle (Bristow et al. 1992), water buffalo (Chen et al. 1996), yak (Long et al. 1999), camel (Mohamed 2006; Guerouali et al. 2004), llama (Bakker et al. 1996), red deer (Vagnoni et al. 1996; Garrott et al. 1996; Christianson and Creel 2010; Zhang and Zhang 2012), and white-tailed deer (DelGiudice et al. 2000; Cabanac et al. 2005). Nevertheless, only a small portion of ruminant species have been investigated, and many environments to which ruminants have adapted do not have a representative species.

We undertook a study intended to determine whether the nutritional status of moose Alces americanus in northeast China was influencing winter survival. We used analyses of purine derivatives in urine, which have been used as indices for evaluation of nutritional condition in various species of domestic (Moorby et al. 2006) and free-ranging (White et al. 1997) ruminants. In the course of that study, we failed to find allantoin in the urine of any Chinese moose. We obtained confirmation of our finding through samples collected on our behalf from North American moose and sent directly to an independent North American metabolomics laboratory for analysis.

The aim of this paper is to report that all non-primate mammals are committed to extending the process of purine degradation to the conversion of uric acid to allantoin, and to suggest that the loss of uricase capability by the moose is adaptive. 


\section{Methods}

Field study

During January in the winters of 2006-2010, we collected 106 frozen urine samples from the surface of the snow at Erkehe Forest, Heilongiiang Province, China $\left(48^{\circ} 39^{\prime} 30^{\prime \prime}-48^{\circ} 48^{\prime}\right.$ $21^{\prime \prime} \mathrm{N} ; 127^{\circ} 59^{\prime} 05^{\prime \prime}-128^{\circ} 15^{\prime} 19^{\prime \prime} \mathrm{E}$ ). January wind chill (WC) ranged from -15.8 to $-50.9^{\circ} \mathrm{C}$, and mean snow depth from 174 to $413 \mathrm{~mm}$. We searched for moose bedding sites, and then followed hoof prints until we found urine deposits. We used hoof-print locations and trajectories to ensure that individual moose were represented no more than once each year. We collected samples into containers, added sulphuric acid to maintain $\mathrm{pH}$ below 3 , and stored them at $-20{ }^{\circ} \mathrm{C}$. For comparison with well-fed moose free of cold stress, during 2012, we arranged for urine from ten well-fed captive moose in Alaska (mean WC on the day of collection $4.1^{\circ} \mathrm{C}$ ) and one in Colorado (WC $15.5{ }^{\circ} \mathrm{C}$ ) to be sent directly to the Metabolomics Laboratory, University of California Davis (UC Davis) Genome Center, for analysis.

\section{Laboratory analysis}

We used HPLC to detect hypoxanthine, xanthine, urate, and allantoin in urine following George et al. (2006). Creatinine was used to standardize against dilution effects. Separation was performed at $25^{\circ} \mathrm{C}$ on a Thermo-Fisher Scientific $\mathrm{C}_{18}$ reversed-phase column $(250 \times 4.60 \mathrm{~mm}, 0.5 \mu \mathrm{m}$ particle size $)$. The mobile phase was a $0.01 \mathrm{~mol} / \mathrm{L}$ potassium dihydrogen phosphate solution. Standard samples were used to identify PD. Peak areas were calculated using Waters Corporation Empower software. Calibration curves were calculated ranging from 1.0 to $200.0 \mu \mathrm{g} / \mathrm{ml}$ for the four PD. Analysis at the Metabolomics Laboratory, UC Davis, of the urine of captive moose was undertaken using liquid chromatographic and gas chromatographic mass spectroscopy following Robertson et al. (2011). All data were converted to molar values to facilitate comparison.

\section{Results}

No allantoin was detected in the samples from free-living moose, but it was unambiguously identified in extremely low concentrations representing a very small proportion of PD (Table 1) in samples from captive moose. In those moose, the molar ratio of allantoin to creatinine was $0.0037 \pm 0.0019$, whereas the normal human molar ratio is 0.0099 (Tolun et al. 2012). By human standards (hyperuricuria $>7 \mu \mathrm{g} / \mathrm{ml}$ ) (Campo et al. 2003), about a quarter of free-living moose in our sample had hyperuricuria. Hence, we conclude that the moose, like the human, has negligible levels of uricase activity.
Table 1 Molar proportions of purine derivatives in the urine of moose (\%)

\begin{tabular}{llllll}
\hline Status & $n$ & Allantoin & Uric acid & Xanthine & Hypoxanthine \\
\hline Captive & 11 & $0.56 \pm 0.29$ & $61.0 \pm 21.2$ & $5.7 \pm 3.2$ & $32.8 \pm 19.3$ \\
Free living & 106 & $\mathrm{ND}^{1}$ & $41.3 \pm 23.8$ & $16.3 \pm 16.6$ & $40.6 \pm 23.9$ \\
\hline
\end{tabular}

$N D$ not detected

\section{Discussion}

The urinary concentrations of purine derivatives reported here for moose are comparable to those in the human, and imply that the moose, like the human and some other primates, is deficient in uricase activity. Human deficiency in uricase was once described as an "inherited genetic defect", but a number of benefits arising from high blood levels of uric acid, mostly based on its antioxidative capacity, have been postulated, particularly related to protection of the nervous system (Álvarez-Lario and Macarrón-Vicente 2011), and the loss of uricase is coming to be regarded as an evolutionary adaptation.

The question, then, is what adaptive function might the loss of uricase activity perform in the moose? We note that exposure to cold disposes to oxidative damage (Siems et al. 1994), and we considered that extreme cold was likely the most significant physiological stressor that the moose is exposed to in its natural environment and one to which it must have adapted. The oxidative damage occurring as a consequence of exposure to cold occurs as a side effect of increased thermogenesis (Venditti et al. 2009) and is also associated with ischemia (Proctor 2008), but uric acid has antioxidative capacity (Álvarez-Lario and Macarrón-Vicente 2011) and there are indications of physiological increases in body uric acid levels in response to exposure to cold, including in humans (Hawkins and Zipkin 1964). Associations have been made between increased blood levels of uric acid and high altitudes in several species including cattle (Ramirez et al. 1992) which were attributed at the time to hypoxia or diet, but those studies were not controlled for temperature, yet a significant and substantial contribution by cold at high altitudes has been demonstrated (Sinha et al. 2010). Further, it has been suggested that high blood uric acid concentrations is an adaptation by llamas to protect against the oxidative damage associated with high altitude cold (Bakker et al. 1996). The moose reduces aerobic and increases anaerobic respiration during winter (Kochan 2007), which suggests a need for a mechanism to reduce oxidative damage. We posit that the moose has adapted to protect itself against the oxidative damage associated with high latitude winter cold by losing uricase activity, the consequence of which would be high levels of uric acid in it blood and hence the high levels that we observed in its urine. 
Acknowledgments The National Natural Science Foundation (No. 30870309) and the Outstanding Ph.D Dissertation Training Plan in Northeast Forestry University (OPTP10-NEFU) are acknowledged for financial support. Jinxue Gu, Yanchang Gu, Shousheng Wang, and Changxin Deng of the DaZhanHe Wetland Management Bureau provided assistance with the fieldwork. John Crouse of the Alaska Department of Fish and Game, Eric Klaphake of Cheyenne Mountain Zoo Colorado, and Vodička Roman of Prague Zoo provided urine from captive moose, and the Metabolomics Research Laboratory, UC Davis, undertook the urinalyses for captive moose.

Open Access This article is distributed under the terms of the Creative Commons Attribution License which permits any use, distribution, and reproduction in any medium, provided the original author(s) and the source are credited.

\section{References}

Álvarez-Lario B, Macarrón-Vicente J (2011) Is there anything good in uric acid? QJM Int J Med 104(12):1015-1024. doi:10.1093/qjmed/hcr159

Bakker ML, Chen XB, Kyle DJ, Orskov ER, Bourke DA (1996) Urinary and plasma purine derivatives in fed and fasted llamas (Lama glama and L-guanacoe). Comp Biochem Physiol B Biochem Mol Biol 113(2):367-374. doi:10.1016/0305-0491(95)02053-5

Belenguer A, Yanez D, Balcells J, Baber NHO, Ronquillo MG (2002) Urinary excretion of purine derivatives and prediction of rumen microbial outflow in goats. Livest Prod Sci 77(2-3):127-135. doi: 10.1016/s0301-6226(02)00081-7

Bristow AW, Whitehead DC, Cockburn JE (1992) Nitrogenous constituents in the urine of cattle, sheep and goats. J Sci Food Agric 59(3): 387-394. doi:10.1002/jsfa. 2740590316

Cabanac AJ, Ouellet JP, Crete M, Rioux P (2005) Urinary metabolites as an index of body condition in wintering white-tailed deer Odocoileus virginianus. Wildl Biol 11(1):59-66. doi:10.2981/ 0909-6396(2005)11[59:umaaio]2.0.co;2

Campo C, Ruilope LM, Segura J, Rodicio JL, Garcia-Robles R, GarciaPuig J (2003) Hyperuricemia, low urine urate excretion and target organ damage in arterial hypertension. Blood Press 12(5-6):277283. doi: $10.1080 / 08037050310019418$

Chen XB, Samaraweera L, Kyle DJ, Orskov ER, Abeygunawardene H (1996) Urinary excretion of purine derivatives and tissue xanthine oxidase (EC 1.2.3.2) activity in buffaloes (Bubalis bubalis) with special reference to differences between buffaloes and Bos taurus cattle. Br J Nutr 75(3):397-407. doi:10.1079/bjn19960142

Christianson D, Creel S (2010) A nutritionally mediated risk effect of wolves on elk. Ecology 91(4):1184-1191. doi:10.1890/09-0221.1

Cutler RG (1984) Urate and ascorbate - their possible roles as antioxidants in determining longevity of mammalian species. Arch Gerontol Geriatr 3(4):321-348. doi:10.1016/0167-4943(84)90033-5

DelGiudice GD, Kerr KD, Mech LD, Seal US (2000) Prolonged winter undernutrition and the interpretation of urinary allantoin: creatinine ratios in white-tailed deer. Can J Zool Rev Can Zool 78(12):21472155. doi:10.1139/cjz-78-12-2147

Garrott RA, White PJ, Vagnoni DB, Heisey DM (1996) Purine derivatives in snow-urine as a dietary index for free-ranging elk. J Wildl Manag 60(4):735-743. doi:10.2307/3802372

George SK, Dipu MT, Mehra UR, Singh P, Verma AK, Ramgaokar JS (2006) Improved HPLC method for the simultaneous determination of allantoin, uric acid and creatinine in cattle urine. J Chromatogr B Anal Technol Biomed Life Sci 832(1):134-137. doi:10.1016/j. jchromb.2005.10.051
Guerouali A, El Gass Y, Balcells J, Belenguer A, Nolan J (2004) Urinary excretion of purine derivatives as an index of microbial protein synthesis in the camel (Camelus dromedarius). Br J Nutr 92(2): 225-232. doi:10.1079/bjn20041208

Hawkins GR, Zipkin I (1964) Effect of prolonged residence in the Antarctica upon some organic constituents of human parotid saliva. Proc Soc Exp Biol Med 117(3):888-891

Hunter A, Givens MH (1914) Studies in the comparative biochemistry of purine metabolism. II. The excretion of purine catabolites in the urine of ungulates. J Biol Chem 18(3):403-416

Keilin J (1959) The biological significance of uric acid and guanine excretion. Biol Rev Camb Philos Soc 34(3):265-296. doi:10.1111/ j.1469-185X.1959.tb01447.x

Kochan TI (2007) Seasonal adaptations of moose (Alces alces) metabolism. Alces 43:123-128

Long RJ, Dong SK, Chen XB, Orskov ER, Hu ZZ (1999) Preliminary studies on urinary excretion of purine derivatives and creatinine in yaks. J Agric Sci 133:427-431. doi:10.1017/s0021859699007169

Mohamed HE (2006) Purine derivatives in the plasma and urine and tissue xanthine oxidase (XO) in Sudanese camels (Camelus dromedarius). J Anim Vet Adv 5(4):310-312

Moorby JM, Dewhurst RJ, Evans RT, Danelon JL (2006) Effects of dairy cow diet forage proportion on duodenal nutrient supply and urinary purine derivative excretion. J Dairy Sci 89(9):35523562

Proctor PH (2008) Uric acid: neuroprotective or neurotoxic? Stroke 39(5):E88-E88. doi:10.1161/strokeaha.107.513242

Ramirez G, Bittle PA, Colice GL, Santacruz R, Hidalgo A, Noguera I, Agosti SJ, Foulis PR (1992) Blood biochemical characteristics of cattle at sea-level and at moderately high-altitude $(3,000 \mathrm{~m})$. Am J Vet Res 53(4):547-550

Robertson DG, Ruepp SU, Stryker SA, Hnatyshyn SY, Shipkova PA, Aranibar N, McNaney CA, Fiehn O, Reily MD (2011) Metabolomic and transcriptomic changes induced by overnight $(16 \mathrm{~h})$ fasting in male and female Sprague-Dawley rats. Chem Res Toxicol 24(4): 481-487. doi:10.1021/tx200074f

Siems WG, Vankuijk F, Maass R, Brenke R (1994) Uric-acid and glutathione levels during short-term whole-body cold-exposure. Free Radic Biol Med 16(3):299-305. doi:10.1016/0891-5849(94) 90030-2

Sinha S, Singh SN, Saha M, Kain TC, Tyagi AK, Ray US (2010) Antioxidant and oxidative stress responses of sojourners at high altitude in different climatic temperatures. Int J Biometeorol 54(1): 85-92. doi:10.1007/s00484-009-0257-9

Surra JC, Guada JA, Balcells J, Castrillo C (1997) Renal and salivary clearance of purine derivatives in sheep. Anim Sci 65:83-91

Tolun AA, Scarbrough PM, Zhang H, McKillop J-A, Wang F, Kishnani PS, Millington DS, Young SP, Il'yasova D (2012) Systemic oxidative stress, as measured by urinary allantoin and F-2-isoprostanes, is not increased in Down syndrome. Ann Epidemiol 22(12):892-894. doi:10.1016/j.annepidem.2012.09.005

Vagnoni DB, Garrott RA, Cook JG, White PJ, Clayton MK (1996) Urinary allantoin: creatinine ratios as a dietary index for elk. $\mathrm{J}$ Wildl Manag 60(4):728-734. doi:10.2307/3802371

Venditti P, Di Stefano L, Di Meo S (2009) Vitamin E reduces coldinduced oxidative stress in rat skeletal muscle decreasing mitochondrial $\mathrm{H} 2 \mathrm{O} 2$ release and tissue susceptibility to oxidants. Redox Rep 14(4):167-175. doi:10.1179/135100009x466113

White PJ, Garrott RA, Heisey DM (1997) An evaluation of snow-urine ratios as indices of ungulate nutritional status. Can J Zool Rev Can Zool 75(10):1687-1694. doi:10.1139/z97-795

Zhang W, Zhang M (2012) Possible nutritional deficiency of the Red Deer (Cervus elaphus) population in the Wanda Mountains, northeast China. Pak J Zool 44(5):1269-1277 